\title{
CONTRIBUTION TO THE MODIFICATION OF INPUT DATA OF SUBGRADE STRUCTURE DIMENSIONING FOR NON-TRAFFIC LOAD ACCORDING TO THE ŽSR METHODOLOGY
}

\author{
LIBOR IŽVOLT, PETER DOBEŠ \& JURAJ PIEŠ \\ Department of Railway Engineering and Track Management, Faculty of Civil Engineering, \\ University of Žilina, Slovakia
}

\begin{abstract}
The Slovak Railways (ŽSR) have been continuously upgrading their main tracks - parts of the TransEuropean corridors. The upgraded tracks must comply with European standards: they must be safe and reliable. The present subgrade structure dimensioning and assessment methodology for non-traffic load (effects of climatic factors, mainly water and snow), as stated in TNŽ 73 6312, does not reflect the current level of knowledge and must be updated. This paper brings some proposals for modification of input data of subgrade structure dimensioning for non-traffic load, in the form of a design map of average annual air temperatures in Slovakia. The original methodology was based on the design map of frost indexes. However, long-term monitoring of subgrade structure freezing confirmed the insufficiency of the original methodology as irrelevant for the subgrade structure design for non-traffic load. The map of average annual air temperatures substantially extends the original methodology.

Keywords: railway track, subgrade structure, subgrade structure freezing, subgrade structure dimensioning, design map of average annual temperatures.
\end{abstract}

\section{INTRODUCTION}

The Slovak Railways (ŽSR) have been continuously upgrading their main tracks - parts of the Trans-European corridors. Within this upgrading, the technical parameters of the tracks are being improved, with the aim of reaching higher track speeds while maintaining high track operation safety and reliability. To meet these goals, it is necessary to be aware of the principles of track behaviour in different operational and climatic conditions. It means that the railway track must withstand the long-term effects of not only traffic (static and mainly dynamic load), but also the non-traffic load (effects of climatic conditions). Due to these facts, the Department of Railway Engineering and Track Management (DRETM) has been paying particular attention to the problem of safety and reliability of railway track with specific focus on non-traffic load [2].

Climatologists are currently able, with certain level of uncertainty, to predict the possible development of the Earth's climate. To meet this purpose, they apply suitable computergenerated climatic models, based on verified physical principles. The fact that the growing concentration of greenhouse gases obviously affects the entire climatic system of the Earth has been well known for a long time. If the growth of greenhouse gas emissions continues, in the second half of the 21 st century we can certainly expect significant changes of climatic conditions. Among them, for example, the assumed growth of global air temperature in 1.1 to $6.4^{\circ} \mathrm{C}$, decrease of snow cover and the occurrence of winter periods with lower frost index. However, winter periods with extreme negative temperatures can also occur among the possible impacts [3]. 


\section{EFFECTS OF THE AVERAGE ANNUAL TEMPERATURE \\ ON RAILWAY TRACK STRUCTURE FREEZING}

The subgrade structure dimensioning for traffic and non-traffic load has been following the standard TNŽ 736312 [1] since 2005. The methodology of subgrade structure protection against the adverse effects of frost (dimensioning for non-traffic load) is based on the design of sufficient thickness of the protective gravel layer. As the respective dimensioning methodology was created in 1960s, it needs to be updated. The updated methodology must consider the current know how (application of new materials in subgrade structure, change of climatic conditions, more demanding requirements for environmental protection, operational safety and reliability).

The problem of monitoring the thermal regime of railway track has been addressed at the Department of Railway Engineering and Track Management (DRETM), of the Faculty of Civil Engineering (FCE, UNIZA) since 2003, when the Experimental stand DRETM I was built. Besides temperature monitoring of various parts of the track structure model (in the 1:1 scale), the research has focused on verification of thermal conductivity coefficients $\lambda$ and monitoring of moisture variations of inbuilt materials of rail track (subgrade structure), exploring the effects of the course of winter period (number of frost periods and the size of frost index) and the average annual temperature on the depth of freezing of subgrade structure (sleeper subgrade). To monitor these properties and characteristics correctly, since 2013 a new experimental stand, named Experimental stand DRETM, is being built. It consists of several measuring profiles. The profiles, which represent the railway track model in the 1:1 scale, differ in the earthwork shape and subgrade structure design. To evaluate the effects of snow cover on the thermal regime of subgrade structure and its depth of freezing, in several winter periods the snow was removed from the model. On the contrary, in some winter periods the snow cover was left on the track substructure or the rail skeleton (approx. $120 \mathrm{~mm})$.

The numerical modeling was conducted parallelly with monitoring of the thermal and water regime of the experimental model and its subgrade. Using the software support ( $\mathrm{SV}$ HEAT SoilVision) [4], it was possible to numerically model the respective winter period the structure was exposed to and subsequently compare the achieved values of its freezing with the values reached at the real structure - measuring profile of the experimental stand [5]-[7].

On the basis of the so far recorded and evaluated climatic characteristics from the experimental stands, several conclusions could have been made. The subgrade structure freezing is not only affected by the size of the frost index (according to the methodology stated in [1] it is the only climatic parameter affecting the design of the protective layer thickness), but also by the length, intensity and the course of the main frost period and by the average annual temperature.

These facts are also reflected in the monitored parameters of the respective winter periods measured on experimental stand DRETM I stated in Table 1. By comparing the frost index and the freezing depth in the winter periods 2005/2006 and 2011/2012, the depth of subgrade structure freezing for the winter period 2011/2012 appears to be greater, even when the value of the air frost index is almost half of its value measured in winter 2005/2006 [5]. The effects of the average annual temperature on the railway track (subgrade structure) freezing were also confirmed by the results of numerical modeling, presented in [6]. 
Table 1: Evaluation of the climatic characteristics for individual winter periods measured on Experimental stand DRETM I [5].

\begin{tabular}{|l|l|l|l|l|l|l|}
\hline Winter period & $\begin{array}{c}\text { Temperature } \\
\theta_{s, \text { max }}\left({ }^{\circ} \mathrm{C}\right)\end{array}$ & $\begin{array}{c}\text { Temperature } \\
\theta_{s, \min }\left({ }^{\circ} \mathrm{C}\right)\end{array}$ & $\begin{array}{l}\text { Frost index } \\
I_{F}\left({ }^{\circ} \mathrm{C} . \text { day }\right)\end{array}$ & $\begin{array}{c}\text { Surface } \\
\text { frost index } \\
I_{F S}\left({ }^{\circ} \mathrm{C} . \text { day }\right)\end{array}$ & $\begin{array}{c}\text { Depth of } \\
\text { freezing } \\
D_{F}(\mathrm{~m})\end{array}$ & $\begin{array}{c}I_{F} \text { for } \\
D_{F, \text { max }} \\
\left({ }^{\circ} \mathrm{C} . \text { day }\right)\end{array}$ \\
\hline $2003 / 2004^{*}$ & 1.19 & -12.31 & -168 & -58 & 0.46 & -29 \\
\hline $2004 / 2005$ & 7.97 & -13.37 & -228 & -143 & 0.70 & -165 \\
\hline $\mathbf{2 0 0 5} / \mathbf{2 0 0 6}{ }^{*}$ & $\mathbf{5 . 7 1}$ & $\mathbf{- 1 6 . 6 8}$ & $\mathbf{- 3 8 8}$ & $\mathbf{- 2 4 8}$ & $\mathbf{0 . 8 2}$ & $\mathbf{- 3 3 4}$ \\
\hline $2006 / 2007$ & 13.02 & -5.26 & -16 & -14 & 0.33 & -9 \\
\hline $2007 / 2008$ & 8.55 & -8.15 & -96 & -91 & 0.48 & -20 \\
\hline $2008 / 2009$ & 11.13 & -11.78 & -150 & -130 & 0.58 & -145 \\
\hline $2009 / 2010$ & 10.40 & -13.27 & -204 & -149 & 0.60 & -145 \\
\hline $2010 / 2011$ & 5.67 & -12.27 & -215 & -145 & 0.61 & -215 \\
\hline $\mathbf{2 0 1 1} / \mathbf{2 0 1 2}$ & $\mathbf{4 . 9 3}$ & $\mathbf{- 1 5 . 2 0}$ & $-\mathbf{2 3 8}$ & $\mathbf{- 2 0 7}$ & $\mathbf{0 . 8 9}$ & $-\mathbf{- 1 8 4}$ \\
\hline $2012 / 2013^{*}$ & 10.68 & -11.45 & -162 & -54 & 0.44 & -107 \\
\hline $2013 / 2014$ & 11.21 & -10.50 & -27 & -33 & 0.46 & -23 \\
\hline $2014 / 2015$ & 9.14 & -8.95 & -40 & -20 & 0.34 & -15 \\
\hline $2015 / 2016$ & 5.1 & -7.6 & -49 & -72 & 0.47 & -49 \\
\hline
\end{tabular}

*with snow cover

2.1 Determination of the coldest year in the period 1967-2017 from the point of view of achieved average annual temperature

Within the research activities of the DRETM, the average annual temperatures from 8 meteorological stations in the Slovak Republic were evaluated. The applied data was provided by the Slovak Hydrometeorological Institute (SHMI).

The studied period was 1967-2017 and the aim was to determine the coldest year in the 50 -year period, (this period is used for subgrade structure dimensioning according to the methodology [1] and [8]). The particular meteorological stations were selected in order to cover the entire Slovak territory. The names and locations of the meteorological stations (marked by green squares), selected from all the existing Slovak meteorological stations, can be seen in Fig. 1.

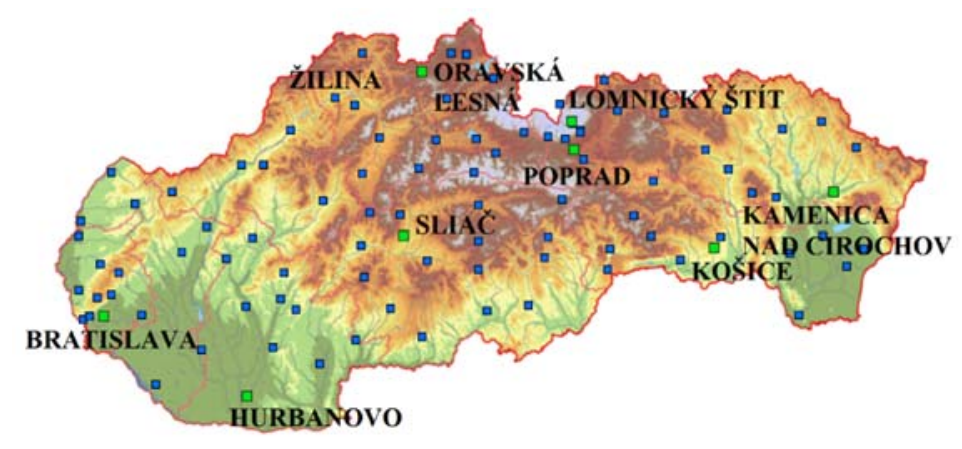

Figure 1: The location of all Slovak meteorological stations and marked selected meteorological stations (bigger green squares) used for determination of the coldest year [9]. 
The achieved lowest average annual temperatures stated for selected meteorological stations in Fig. 1 are presented in Table 2. All the average annual air temperatures were achieved in one year (1980).

2.2 Determination of dependence of the achieved minimum average annual temperature on altitude

It is typical of the lowest layer of the atmosphere (troposphere) that the air temperature decreases with altitude, i.e. that on the Earth's surface the air is warmer than the air in the certain height above it. It is caused by heating the Earth's surface, which radiates the heat obtained by the absorbed solar radiation.

Heat transfer from the Earth's surface is accompanied by the convection phenomenon, when the heated air rises and the cold air presses in from above to its place. The temperature of the rising air increases with the decreasing air pressure at higher heights (adiabatic process). The decrease of the air temperature in lower atmospheric layers (up to about $11 \mathrm{~km}$ ) is approx. $1{ }^{\circ} \mathrm{C}$ for $150 \mathrm{~m}$ of height, thus approx. $0.65^{\circ} \mathrm{C}$ for each $100 \mathrm{~m}[10]$.

As stated above, when the achieved average annual air temperatures $\theta_{m}$, were evaluated, the coldest year in the monitored period was 1980. Due to this, we asked the SHMI to provide us with data for determination of the average annual air temperature for other meteorological stations (Fig. 1 shows their location marked by blue square). Their number, also with the abovementioned ones, is 103. Unfortunately, some meteorological stations reported technical problems with continuous data recording, or they did not exist then and therefore they could not have been considered for the determination of the annual air temperature. These stations are: Topol’čany, Vel'ký Kliž, Mochovce, Žilina, Dolný Kubín, Dolný Kubín (Kňažia), Malatiná, Liptovská Mara, Košice (Podhradová), Jablonov nad Turňou, Vyšná Jablonka and Ulič. With regard to these facts, for evaluating and determining the respective dependence, the data from altogether 91 Slovak meteorological stations was applied.

The Fig. 2 presents the dependence of the average annual air temperature $\theta_{m}$ on altitude in 1980 and for the set of 91 Slovak meteorological stations.

On the basis of the achieved relation of dependence of the average annual air temperature $\theta_{m}$ on altitude, demonstrated in Fig. 2, we subsequently determined the altitudes where the average annual air temperature achieved the values $4,5,6,7$ and $8^{\circ} \mathrm{C}-$ Table 3 .

Table 2: Minimum average annual air temperatures $\theta_{m}$ stated for selected Slovak meteorological stations in 1967-2017.

\begin{tabular}{|l|c|c|}
\hline Station & $\begin{array}{c}\text { Altitude } \\
(\mathrm{m} \text { a.s.1.) }\end{array}$ & $\begin{array}{c}\text { Minimum average } \\
\text { annual temperature } \\
\theta_{m}\left({ }^{\circ} \mathrm{C}\right)\end{array}$ \\
\hline Bratislava - airport & 133 & 8.7 \\
\hline Hurbanovo & 115 & 8.7 \\
\hline Kamenica nad Cirochou & 176 & 7.1 \\
\hline Košice - airport & 230 & 7.2 \\
\hline Lomnický štít & 2635 & -5.0 \\
\hline Oravská Lesná & 780 & 3.5 \\
\hline Poprad & 694 & 4.8 \\
\hline Sliač & 313 & 7.0 \\
\hline
\end{tabular}

* m a.s.l. - meters above sea level. 


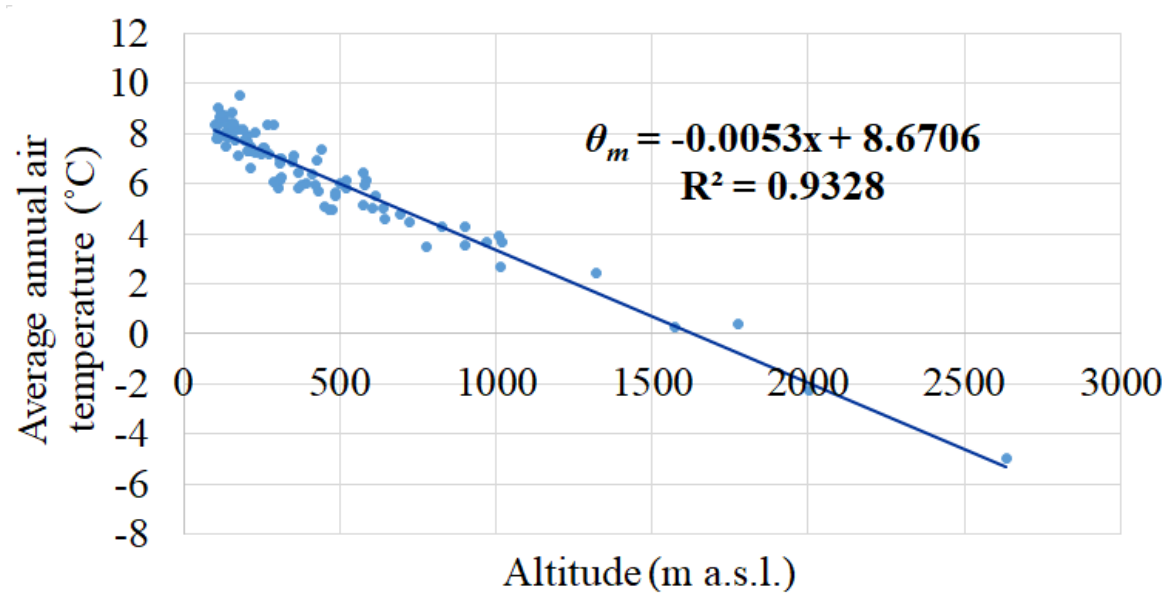

Figure 2: Dependence of the average annual air temperature $\theta_{m}$ on altitude in 1980.

Table 3: The resulting altitudes for particular average annual air temperatures.

\begin{tabular}{|c|c|}
\hline $\begin{array}{c}\text { Average annual air } \\
\text { temperature }\left({ }^{\circ} \mathrm{C}\right)\end{array}$ & $\begin{array}{c}\text { Altitude } \\
\text { (m a.s.l.)* }\end{array}$ \\
\hline 4 & 125 \\
\hline 5 & 315 \\
\hline 6 & 500 \\
\hline 7 & 690 \\
\hline 8 & 880 \\
\hline * m a.s.l. - meters above sea level.
\end{tabular}

\subsection{The design map of the average annual air temperatures in 1967-2017}

The design methodology of subgrade structure dimensioning for the adverse effects of frost stated in [1] is based on the coldest year in last 50 years. The main parameter affecting the thickness design of the frost-susceptible subgrade surface (protective layer) of subgrade structure is, according to [1], only the value of the frost index. Therefore, for dimensioning of the structural thickness of the protective layer, the relevant legislative document only states the design map of frost indexes for the Slovak territory. The most serious deficiency of this design map is the fact that it was created for the winter period 1962/1963. It is thus unrepresentative, as it is beyond the required period (coldest winter in last 50). At the same time, it is advisable to consider the effects of other factors affecting the depth of freezing of railway track (subgrade structure), identified during experimental measurements and numerical modeling of the thermal regime of the railway track structure in last 15 years, (at the Department of the authors of this paper). These facts suggest that it is not only necessary to update the existing map of the design frost indexes in Slovakia but also to create a map of average air temperatures $\theta_{m}$ in the Slovak territory affecting the thermal regime of the winter period. The data provided by the SHMI suggests that the coldest year from the point of view of the average air temperature (year 1980) does not correlate with the coldest winter period expressed by the achieved frost index (winter period 1986/1987). Due to this, the provided data was only applied in creating the map of minimum average annual temperatures in 


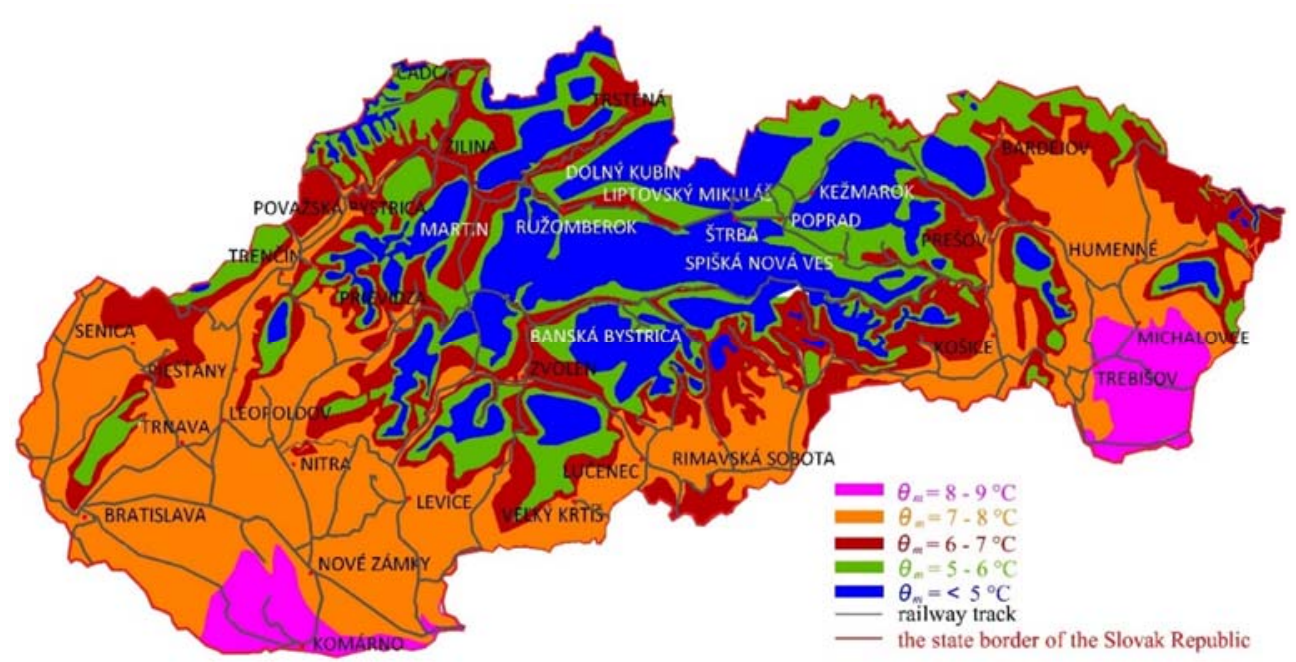

Figure 3: Map of minimum average annual temperatures in Slovakia in 1967-2017.

Slovakia in last 50 years (Fig. 3). It will be necessary to create the map of design frost indexes for the respective winter period, which is one of the goals of our future research.

The incorporation of the parameter of the average annual air temperature $\theta_{m}$ into the dimensioning procedure of the structural thickness of the protective layer of the frostsusceptible subgrade surface for the adverse effects of frost was enhanced by the fact that this parameter is also considered in the dimensioning of structure and thickness of roads [11]. The standard [1], Appendix A, contains the design map of the average annual air temperatures $\theta_{m}$ in the Slovak territory, created by VUIS-CESTY, Ltd., Bratislava. In this case, however, it is not known for which period the respective map of design values of average annual air temperatures $\theta_{m}$ is valid. If we compare the design map stated in Fig. 3, with the design map stated in [11], it is possible to conclude that the difference of average annual air temperatures $\theta_{m}$ in some areas of Slovakia in the design map stated in [11] is higher in $2^{\circ} \mathrm{C}$. This difference is also caused by the fact that the design map of the average annual air temperatures does not consider the identified lowest average annual temperatures in the monitored period, but only the arithmetic average of all average annual air temperatures $\theta_{m}$ in that period.

\section{CONCLUSION}

Even despite the changes of the climatic system of the Earth and continuously increasing average air temperature, minimally once in 10 years an occurrence of a year with a very low average annual air temperature or a winter period with a high value of the frost index is recorded in Slovakia. It is also interesting to notice that in the last 50 years, the year with the lowest average air temperature has not been the year with the maximum value of the frost index.

On the basis of the long-term monitoring of the thermal regime of the railway track structure (subgrade structure) at the DRETM, we can state that the frost index is not the only parameter affecting the freezing of the railway track structure (subgrade structure). It would thus be advisable to consider the average annual air temperature $\theta_{m}$ in the dimensioning methodology of subgrade structure for non-traffic load (adverse effects of frost) stated in [1]. 
The main reason is that this temperature affects the amount of heat accumulated in the track structure (in the rail bed, earthwork and subgrade) before the winter period and subsequently also the location of the zero isotherm in the track structure (subgrade structure) in relation to the subgrade surface.

As obvious from Part 2 (Fig. 2), the dependence of the average annual air temperature $\theta_{m}$ and altitude shows a high level of correlation, therefore it is possible to consider the data of average annual air temperature in relation to altitude and vice versa, stated in Table 3 , as relevant. At the same time, it is possible to state that this dependence has a high information value and the design map of the minimum average annual air temperatures $\theta_{m}$ (Fig. 3) is also relevant. As it is not probable that the coldest year would interlap with the winter period with the highest frost index, it would be more suitable to create a design map based on statistical evaluation of average annual air temperatures $\theta_{m}$ - as an arithmetic average of values of average annual air temperatures $\theta_{m}$ in a 50-year period. Such a design map of average annual temperatures would require an availability of significant amount of data on average daily air temperatures in a monitored period from all Slovak meteorological stations. This data would have to be provided by the SHMI and its processing would be time-demanding and costly.

\section{ACKNOWLEDGEMENT}

The presented results are the results of solving the VEGA grant project 1/0275/16 Optimization design of sleeper subgrade due to non-traffic load aspect.

\section{REFERENCES}

[1] TNŽ 73 6312, Design of Structural Layers of Subgrade Structures, GR ŽSR: Slovakia, 2005.

[2] Ižvolt, L., Dobeš, P. \& Pultznerová, A., Contribution to the subgrade structure dimensioning for non-traffic load, STRAHOS 2016. Proceedings of 17th Seminar of Railway Tracks, Pieštany, 28th and 29th April 2016, University of Žilina, Faculty of Civil Engineering, Department of Railway Engineering and Track Management, pp. 41-52, 2016. http://svf.uniza.sk/kzsth.

[3] http://www.shmu.sk/sk/?page=1069\&highlight $=2075$.

[4] SVHEAT, 2D/3D Geothermal Modelling, SVOFFICE 2009 - Geotechnical Modelling Suite, SoilVision Systems Ltd.: Saskatoon, Saskatchenwan, Canada, 2016. http://www.soilvision.com.

[5] Dobeš, P., Optimization of the subgrade design for non-traffic load. Doctoral dissertation, University of Žilina, Faculty of Civil Engineering, Department of Railway Engineering and Track Management, 136 pp., 2015. http://svf.uniza.sk/kzsth.

[6] Ižvolt, L. \& Dobeš, P., Mathematical modeling of the various factors impact on the frost depth of subgrade construction. Procedia Engineering, XXIV Russian-SlovakPoland Seminar, Theoretical Foundation of Civil Engineering, 111(2015), pp. 331338, 2015, Online. http://www.sciencedirect.com/science/article/ pii/S1877705815013466.

[7] Hodás, S. \& Pultznerová, A., Modelling of railway track temperature regime with real heat-technical values for different climatic characteristics. Civil and Environmental Engineering, De Gruyter, University of Žilina, Faculty of Civil Engineering, 13(2), pp. 134-142, 2017, Online. https://www.degruyter.com/view/j/cee.2017.13.issue2/cee-2017-0018/cee-2017-0018.xml?format=INT.

[8] Decký, M., Frost index evaluated from air temperature measurements since 1971 to 2006 in the territory of the Slovak Republic. Silniční Obzor, 71(2), pp. 40-45, 2010. 
252 Computers in Railways XVI

[9] http://www.shmu.sk/File/Klima/zoznam_klimatologickych_stanic_SK.pdf.

[10] https://cs.wikipedia.org/wiki/Inverze_teploty_vzduchu.

[11] STN 73 6114, Pavement of Roads Basic Provision for Structural Design, GR ŽSR: Slovakia, 2005. 